\title{
Unveiling the food webs of tetrapods across Europe through the prism of the Eltonian niche
}

\author{
Louise M. J. O'Connor ${ }^{1}$ (D) | Laura J. Pollock ${ }^{1,2}$ | João Braga ${ }^{1}$ | \\ Gentile Francesco Ficetola ${ }^{1,3}$ (D) | Luigi Maiorano ${ }^{4}$ | Camille Martinez-Almoyna ${ }^{1}$ | \\ Alessandro Montemaggiori $^{4}$ | Marc Ohlmann ${ }^{1}$ | Wilfried Thuiller ${ }^{1}$ (D)
}

${ }^{1}$ Univ. Grenoble Alpes, CNRS, Univ. Savoie Mont Blanc, LECA, Laboratoire d'Écologie Alpine, Grenoble, France

${ }^{2}$ Department of Biology, McGill University, Montreal, QC, Canada

${ }^{3}$ Department of Environmental Sciences and Policy, Università degli Studi di Milano. Via Celoria, Milano, Italia

${ }^{4}$ Department of Biology and Biotechnologies "Charles Darwin", Università di Roma "La Sapienza", Rome, Italy

\section{Correspondence}

Louise M. J. O'Connor, Univ. Grenoble Alpes, CNRS, Univ. Savoie Mont Blanc, LECA, Laboratoire d'Écologie Alpine, F- 38000 Grenoble, France.

Email: louise.mj.oconnor@gmail.com

Funding information

Agence Nationale de la Recherche, Grant/ Award Number: ANR-18-EBI4-0009;

Agence Nationale pour la Recherche, Grant/ Award Number: ANR-18-MPGA-0004

Handling Editor: Damaris Zurell

\begin{abstract}
Aim: Despite recent calls for integrating interaction networks into the study of large-scale biodiversity patterns, we still lack a basic understanding of the functional characteristics of large interaction networks and how they are structured across environments. Here, building on recent advances in network science around the Eltonian niche concept, we aim to characterize the trophic groups in a large food web, and understand how these trophic groups vary across space.

Location: Europe and Anatolia.

Taxon: Tetrapods (1,136 species).

Methods: We combined an expert-based metaweb of all European tetrapods with their spatial distributions and biological traits. To understand the functional structure of the metaweb, we first used a stochastic block model to group species with similar Eltonian niches, and then analysed these groups with species' functional traits and network metrics. We then combined these groups with species distributions to understand how trophic diversity varies across space, in function of the environment, and between the European ecoregions.

Results: We summarized the 1,136 interacting species within the metaweb into 46 meaningful trophic groups of species with a similar role in the metaweb. Specific aspects of the ecology of species, such as their activity time, nesting habitat and diet explained these trophic groups. Across space, trophic diversity was driven by both biotic and abiotic factors (species richness, climate and primary productivity), and the representation of trophic groups differed among European ecoregions.

Main conclusions: We have characterized the Eltonian niche of species in a large food web, both in terms of species interactions and functional traits, and then used this to understand the spatial variation of food webs at a functional level, thus bringing together network science, functional ecology and biogeography. Our results highlight the need to integrate multiple aspects of species ecology in global change research. Further, our approach is strongly relevant for conservation biology as it could help predict the impact of species translocations on trophic diversity.
\end{abstract}




\section{KEYWORDS}

food webs, functional traits, metaweb, stochastic block model, trophic diversity, trophic groups

\section{1 | INTRODUCTION}

Understanding spatial biodiversity patterns and underlying ecological processes is a central research axis of biogeography (Humboldt $\&$ Bonpland, 1805). Owing to the historical importance of this issue, its current relevance for conservation, and its revived momentum in the era of big data, recent work has allowed new comprehensive syntheses on the ecological and evolutionary drivers of large-scale diversity patterns (Ficetola, Mazel, \& Thuiller, 2017; Jetz, Thomas, Joy, Hartmann, \& Mooers, 2012; Mazel et al., 2017). The majority of these studies have used functional or phylogenetic information to group species or quantify diversity (Davies \& Buckley, 2011; Safi et al., 2011). While functional and phylogenetic data have offered many insights into ecological processes (e.g. Sundstrom, Allen, \& Barichievy, 2012), they are only indirect proxies for how species interact in communities. Biotic interactions, such as trophic interactions, can shape macroecological patterns of diversity (Gotelli, Graves, \& Rahbek, 2010), in addition to the better-known effects of the abiotic environment. Especially in the context of global change, where species interactions are altered (Valiente-Banuet et al., 2015), with cascading effects on the response of multiple species to global change (Bascompte, García, Ortega, Rezende, \& Pironon, 2019; Tylianakis, Didham, Bascompte, \& Wardle, 2008; Van der Putten, Macel, \& Visser, 2010; Wisz et al., 2013), it is of prime importance to integrate the interaction networks into the study of biodiversity patterns (Baiser et al., 2019; Pellissier et al., 2017; Tylianakis \& Morris, 2017).

Food webs are particular interaction networks that represent both the species composition of a community together with the fluxes of biomass associated with their interactions, thus providing the potential to reconcile the structure and function of biodiversity (Thompson et al., 2012). So far, food webs have been analysed and compared across space through either network-level metrics or species-level metrics (Baiser et al., 2019; Kortsch et al., 2019), but we still lack the capacity to unveil how large food webs are structured in terms of the roles of the species that compose them, and consequently to understand how the structure and function of food webs vary across environmental gradients (Pellissier et al., 2017). Both the complexity of interaction networks and the scarcity of empirical interaction network datasets across large spatial scales have hindered this progress.

One approach to reduce the complexity of large food webs while preserving their structure is to group the species together based on their role in the food web, or their Eltonian niche, defined as the 'place of an animal in a community, its relation to food and enemies' (i.e. to prey and predators; Elton, 1927). There have been two lines of research that seek to understand the role of species in food webs. The first approach focuses on the position of a species within a food web, using methods from network science to aggregate species into a number of trophic groups that contain species with similar sets of prey and predator species (Cirtwill et al., 2018). The stochastic block model (Allesina \& Pascual, 2009; Daudin, Picard, \& Robin, 2008; Karrer \& Newman, 2011), in particular, provides the opportunity to aggregate the species that have the same probability of interacting with the rest of the species in the network, i.e. similar Eltonian niches (Gauzens, Thébault, Lacroix, \& Legendre, 2015). The second approach focuses on the use of functional traits to deduce the role of a species within a food web and infer their interactions (Gravel, Albouy, \& Thuiller, 2016). For example, a trophic interaction between two species results from a match between the vulnerability traits of the prey species and the foraging traits of the predator species (Gravel et al., 2016; Rossberg, Brännström, \& Dieckmann, 2010). Characterizing a species from its position in the network topology on the one hand, and from its functional traits on the other, have thus been two contrasting approaches to determine a species' Eltonian niche. However, integrating both perspectives to understand how and which biological traits define the role of species in a food web has seldom been investigated (Baskerville et al., 2011; Coux, Rader, Bartomeus, \& Tylianakis, 2016; Kéfi, Miele, Wieters, Navarrete, \& Berlow, 2016). Here, we used a novel food web dataset of all European tetrapod species to merge these approaches by first modelling the trophic role (or Eltonian niche) of species in the food web using recently developed methods in network science, and then describing how these trophic roles relate to species' functional traits. We expect the food web to be structured into functionally meaningful trophic groups that aggregate species with overlapping sets of prey and predator species in the food web, due to similarities in their foraging and vulnerability traits (Laigle et al., 2018).

Combined with the species' geographic distributions, the Eltonian niche concept further enables the structure of food webs to be portrayed across space, adding a new dimension to spatial biodiversity patterns. Trophic diversity, defined as the number of trophic roles played by species (Bascompte, 2009), appears as a convenient measure to map food web patterns across macroecological scales. Ecogeographical rules observed for species richness, such as the latitudinal gradient, have not yet been investigated for species roles in food webs (Baiser et al., 2019), and divergences between species richness and trophic diversity patterns have the potential to reveal the underlying ecological processes driving the patterns of biodiversity at macroecological scales. We expect different environments to select the species based on their role in interaction networks (Tylianakis \& Morris, 2017). For instance, in more favourable climatic conditions and more productive ecosystems, high competition for resources should lead to high trophic specialization and trophic complementarity (Poisot, Mouquet, \& Gravel, 2013), translating into a more diverse range of trophic roles filled locally, therefore a higher trophic diversity, than in harsher environmental conditions with the same number of species (Gaston, 2000). 
Here, following on recent calls to bridge the gap between contrasting views of the niche (Gravel et al., 2018), we built a large food web made up of the 50,408 potential trophic interactions between all the tetrapod species across Europe (i.e. the metaweb of 1,136 species of birds, reptiles, amphibians and mammals). We first inferred trophic groups in the metaweb using the stochastic block model and investigated the functional trait structure of these trophic groups. Second, we combined the metaweb with species distribution data, to explore how these trophic groups vary across space, in quantity and in quality. We hypothesized that: (a) the metaweb of European tetrapods can be simplified into trophic groups which are determined by the functional traits of the species that compose them, and (b) divergences between the patterns of trophic diversity and those of species richness across the European continent should provide insights into the underlying ecological processes that contribute to the food web structure and function at macroecological scales.

\section{2 | MATERIALS AND METHODS}

An overview of the material and methods is depicted in Figure S1.

\section{1 | Study area, species distributions and biological traits}

The study area included Europe (including Macaronesia and Iceland) and Anatolia. We extracted the distributions for all tetrapods naturally occurring within the study area from Maiorano et al. (2013), which were modelled by combining the extent of occurrence for each species with their habitat requirements (see Maiorano et al., 2013 for a full description of species distribution data). In total, our analyses focused on 508 bird, 288 mammal, 237 reptile and 103 amphibian species. Species distributions were mapped in a regular grid of 300 m resolution, where cells had values of zero for unsuitable habitat, one for marginal habitat (habitat where the species can be present, but does not persist in the absence of primary habitat; Maiorano et al., 2013) and two for primary habitat. Here, we treated primary habitat only as 'suitable habitat', which provides a better prediction of the actual species distribution (Ficetola, Rondinini, Bonardi, Baisero, \& Padoa-Schioppa, 2015). All range maps were upscaled to a $10 \times 10 \mathrm{~km}$ equal-size area grid (ETRS89; total of 78,873 cells). We considered the species potentially present in a $10 \times 10 \mathrm{~km}$ cell when they had least one $300 \mathrm{~m}$ suitable habitat cell within it.

For the same set of species, we gathered biological trait data from Thuiller et al. (2015). We used traits that are linked to trophic interactions (Luck, Lavorel, McIntyre, \& Lumb, 2012) and restricted our analyses to comparable traits between the four groups. These consisted of information on:

- diet (17 categories: mushrooms, seeds/nuts, fruits/berries, mosses/lichens, vegetative plant parts, invertebrates, vertebrates, fish, small mammals, large mammals, herptiles, bird eggs, small birds, large birds, bones, carrion, coprophagous)
- nesting habitat (tree hole, ground, rocks, artificial, underground water, cave/burrow, lodge, temporary water, brooks/springs/ small rivers, puddles/ponds, brackish waters)

- activity time (diurnal, crepuscular, nocturnal, arrhythmic)

- foraging behaviour (grazer, opportunistic, hunter, browser)

- morphology (body mass for birds and mammals, body length for herptiles).

\section{2 | The network of potential trophic interactions}

The network of potential trophic interactions between all European tetrapod species (hereafter, the metaweb) was built using a combination of expert knowledge, published information and field guides (a list of references is found in Appendix 1). Trophic interactions between a predator and its prey were identified from published accounts of their observation, morphological similarities between potential prey and literature-referenced prey and, in the absence of this information, the diet of the predator's sister species. The full dataset and methods description is available in the Dryad data repository. The metaweb contained 1,136 tetrapod species and a total of 50,408 potential trophic interactions. In this metaweb, 883 basal species did not prey on European tetrapod species (i.e. basal species here could feed on plants, detritus, invertebrates, fish, domestic animals or were coprophagous), 213 intermediate consumer species had both prey and predator species among European tetrapods and 40 top predator species had no predator species. The metaweb had a connectance of 0.0385 .

\section{3 | Trophic groups definition}

To build trophic groups, we used a stochastic block model (SBM) on the metaweb of potential trophic interactions (R-package mixeR version 1.8 Daudin et al., 2008; Miele, 2006)), following previous studies (Baskerville et al., 2011; Gauzens et al., 2015; Kéfi et al., 2016; Mariadassou, Robin, \& Vacher, 2010). The SBM is a random graph model with several groups of nodes (also known as 'group model' in Allesina and Pascual (2009) or 'block model' in Newman and Leicht (2007)). A parameter of this model is an aggregated graph with groups of nodes, linked to one another through edges that represent the probability of connection between any two nodes in the corresponding groups. Consequently, two nodes belonging to the same group have the same probability of connection with all other nodes in the graph. Given a network, the statistical machinery of the SBM aims to recover the groups defining similar groups of species in terms of the interactions they have with each other (Gauzens et al., 2015). The goodness of fit of the model is assessed using the integrated classification likelihood (ICL) information criterion. Applied to the metaweb, the SBM inferred groups of species such that two species belonged to the same group if they had the same probability of interacting with all other species in the metaweb - in other words, they potentially preyed on similar sets of species, and were potentially 
preyed upon by similar sets of species. Using the SBM, we partitioned the species in the metaweb along a range of 10-60 groups, hereafter referred to as trophic groups. We defined the optimal number of groups based on the partitioning of the metaweb that maximized the ICL criterion (Figure S2). We then computed the average trophic level of each trophic group (R-package Netlndices (version 1.4.4; Soetaert, Kipyegon Kones, \& van Oevelen, 2015)). We also computed the in- and out-degree of the species (defined as the number of predator and prey links of a species respectively) in the potential metaweb (R-package igraph (version 1.2.4; Csárdi, 2019)) and expressed the distribution of in- and out-degree within each trophic group (Figure S3).

\subsection{Functional composition of trophic groups}

To visualize the metaweb, we removed the links between species that never co-occurred in space (in terms of range and habitat cooccurrence) and used the software Gephi (version 0.9.2, Bastian, Heymann, \& Jacomy, 2009; Figure 1). We then described the composition of the groups in terms of the taxonomy (at the class level) and generalism of the species (Figure S3).

We then performed a multivariate analysis to understand the composition of trophic groups in terms of the biological traits of the species they contained. We did so using a co-inertia approach called the Outlying Mean Index (Dolédec, Chessel, \& Gimaret-Carpentier, 2000) that is usually meant to identify the ecological niche of species as a function of the environment (function niche in package ade 4 (version 1.7-13) in R (Dray, Dufour, \& Thioulouse, 2018)). Here, we took advantage of this approach to characterize the different trophic groups (species $x$ trophic groups matrix) as a function of the biological traits (species $x$ traits matrix). In other words, we mapped the trophic groups in the space of the functional traits of the species they contained.

\subsection{Quantifying and mapping trophic diversity across Europe}

To characterize how trophic diversity varied across space, we first mapped trophic diversity (as the number of trophic groups found in each grid cell) with species richness (the number of species in each grid cell). Then, we tested the response of trophic diversity to species richness, environmental variables and the interactions between these drivers using a linear model. Bioclimatic data at $10 \mathrm{~km}$ resolution and net primary productivity (NPP) were downloaded from Worldclim v2 (http://www.worldclim.org) and SEDAC (https://sedac.ciesin.columbia. edu/data/collection/hanpp/sets/browse) respectively. We tested the pairwise correlations between all environmental variables and selected those that were not correlated (Figure S4). We then ran linear models

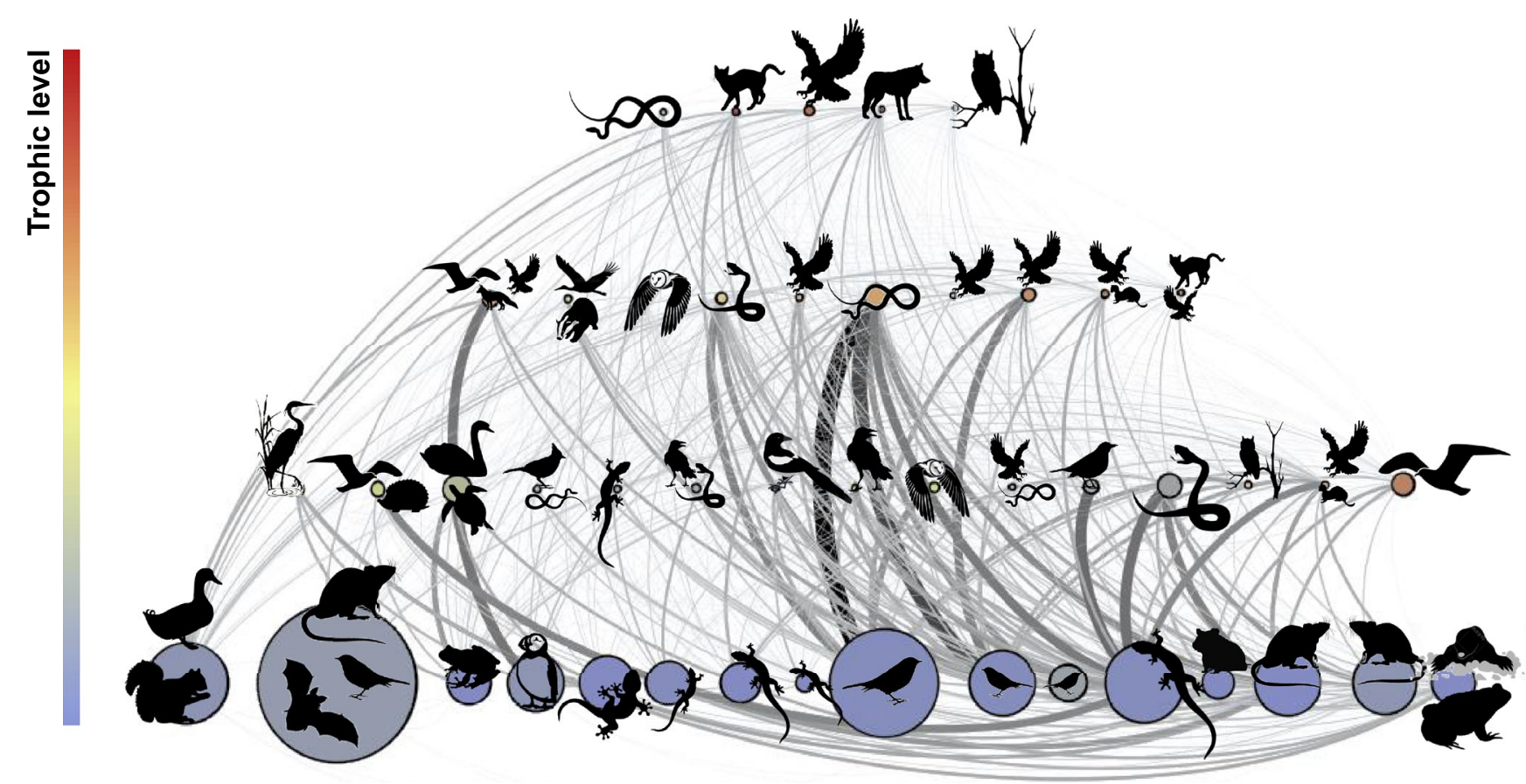

FIGURE 1 Trophic groups as a function of trophic level. The nodes of this network represent the trophic groups, with their size proportional to the number of species in the group. Groups are positioned according to the average trophic level of the species they contain, from the bottom of the metaweb (basal preys) to the top (top predators), and coloured according to in-degree (i.e. predatory generalism). Silhouettes represent the characteristic species found in each trophic group and reflect the taxonomic coherence of these groups. The width and intensity of the links between two given groups represent the number of realized links between them - that is, the number of species pairs belonging to both groups and that co-occur at least once in Europe [Colour figure can be viewed at wileyonlinelibrary.com] 
accordingly with different combinations of explanatory variables and selected the model with the smallest AIC. We mapped the residuals of the linear model including species richness alone and compared it with the residuals of the full model (that included average annual temperature, net primary productivity and temperature seasonality in addition to species richness; Figure S5). Finally, to understand how each environmental variable influenced the relationship between species richness and trophic diversity, we computed the predictions of the linear model for the first, second and third quartile of each environmental variable to plot their statistical interaction with species richness.

We then investigated how the trophic groups and types of interactions in the tetrapods' food web varied across the different European ecoregions, defined by the European Environment Agency (EEA, 2019) to represent 'extents of areas in Europe with relatively homogeneous ecological conditions, on the basis of climatic, topographic and geobotanical data, within which comparisons and assessments of different expressions of biodiversity are expected to be meaningful'. We compared ecoregional metawebs across 11 ecoregions: alpine, Anatolian, arctic, atlantic, boreal, Black Sea, continental, Macaronesia, Mediterranean, Pannonian and steppic. We built each ecoregional metaweb by sampling the species occurring in the ecoregion and the interactions between co-occurring species within the ecoregion from the European metaweb. We then aggregated each ecoregional metaweb using the 46 trophic groups defined in the European metaweb. The links between two given groups represented the sum of interactions realized in the ecoregion (i.e. the number of pairs of species belonging to these groups that co-occurred and interacted in the ecoregion). We also computed the geographic specialization of species to each European ecoregion (computed as the ratio between a species' ecoregional range and its European range), then computed the median value of specialization for each group.

All analyses were conducted in R version 3.4.3 (R Core Team, 2017).

\section{3 | RESULTS}

\section{1 | Defining trophic groups in the European metaweb of tetrapods' trophic interactions}

Based on the ICL criterion, the SBM partitioned the European metaweb into 46 groups (Figure S2). A qualitative examination of the partitioning suggested that groups were homogenous in terms of taxonomy, trophic level and the degree of generalism of the species within them (Figure 1; Figure S2). We organized the 46 trophic groups within four trophic levels to visualize the flow of biomass, from herbivores to intermediate consumers, mesopredators and finally top predators.

The outlying mean index revealed that specific traits strongly explained the trophic groups (Figure 2). The first component was primarily driven by the feeding behaviour and the diet of species, with secondary consumers and carnivores (e.g. hunters) belonging to different trophic groups than herbivore species (e.g. grazers and browsers), consistent with the organization of the trophic groups into the aforementioned trophic levels. The second component was driven by the activity time and the nesting habitat of species, with diurnal species separated from nocturnal species in these trophic groups, meaning that the time of activity determines the types of prey or predator of a species, and species nesting in aquatic habitat belonging to different trophic groups than species nesting in terrestrial habitat. This second component especially structured the trophic groups within intermediate and basal trophic levels.

\section{2 | Mapping trophic diversity across Europe}

Trophic diversity generally decreased with latitude in a similar manner to species richness - that is, there was a latitudinal gradient for trophic diversity as well for species richness (Figure 3A,B). Species richness and trophic diversity were both at their lowest in northern latitudes. Several trophic groups (e.g. groups composed by herptiles)
FIGURE 2 Trait niche of trophic groups. This bi-plot characterizes the mean position of each trophic group along the two-dimensional space represented by the species biological traits. Traits are coloured according to their category (activity time, secondary consumer characteristics, primary consumer characteristics, aquatic or terrestrial nesting habitat type). The length and orientation of each arrow reflects the relative importance of a given trait in explaining the variation between the groups. Groups are positioned in this multivariate space and represented by the same silhouettes as in Figure 1 [Colour figure can be viewed at wileyonlinelibrary. com]

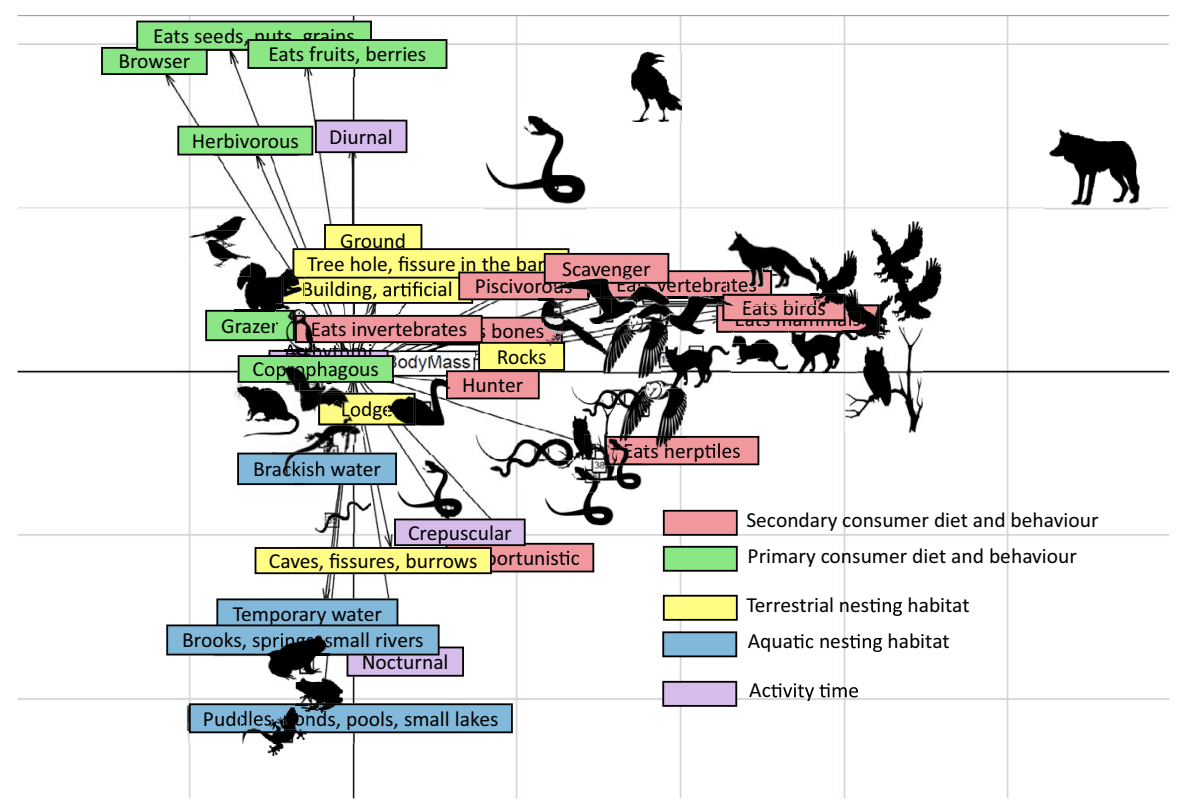




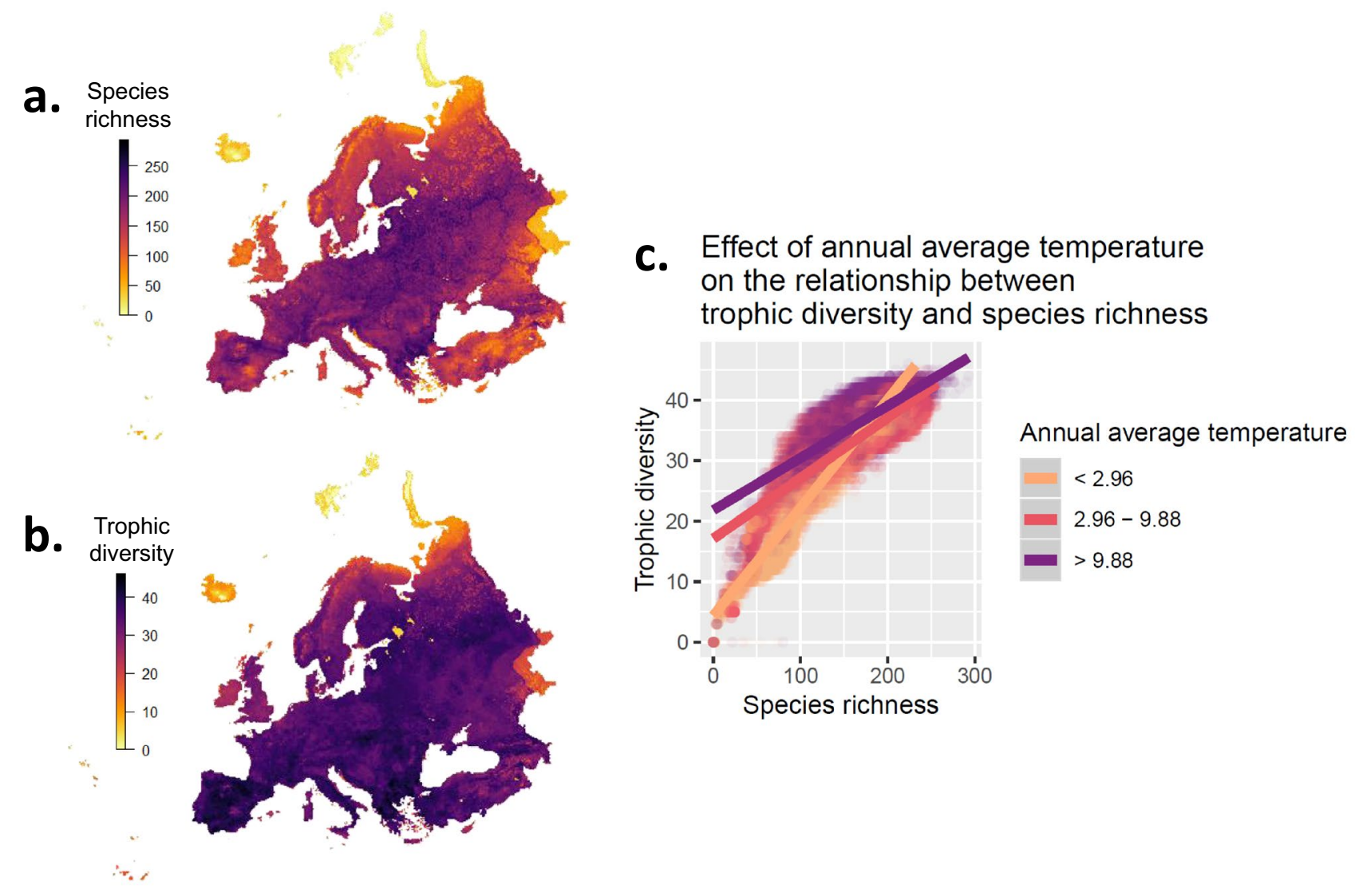

FIGURE 3 Species richness and trophic diversity across Europe. a, b: Maps representing species richness and trophic group richness across Europe. c: Interaction plot between annual mean temperature and species richness in driving trophic diversity. The scatterplot of trophic diversity as a function of species richness is overlaid with the interaction plot between the annual average temperature and species richness effects on trophic diversity, based on predictions from the linear model. The three categories of annual average temperature represent the first, second (median) and third quartiles. The lines and the data points in the scatterplot are coloured accordingly to these three categories [Colour figure can be viewed at wileyonlinelibrary.com]

were completely absent from both the arctic and boreal ecoregions, reducing the complexity of these regional metawebs (Figure 4), parallel to a regional decrease in trophic diversity. Because of these low diversities, a single type of interaction was strongly represented in the Arctic metaweb, involving a group of mesopredators (e.g. predatory seabird species and the arctic fox) preying on a group of basal species in the Arctic (mainly small birds and rodents). Then, trophic diversity and species richness both peaked at intermediate latitudes (Figure 3A,B): species richness peaked at around 600 species $/ 100 \mathrm{~km}^{2}$ and trophic group diversity peaked at 46 groups $/ 100 \mathrm{~km}^{2}$, frequently reaching these highest values in mountainous areas. To illustrate, the alpine metaweb displayed the highest species richness, trophic diversity and link density of all ecoregional metawebs (Figure 4). However, in southern Europe, trophic diversity patterns diverged from species richness patterns (Figure 3A,B) - trophic diversity remained close to its maximum, while species richness was lower in southern Europe than in intermediate latitudes. This was exemplified with the Mediterranean and Anatolian metawebs in southern Europe (Figure 4), where all trophic groups of the European metaweb were represented by at least one species, but with fewer species representing them overall, than in the alpine metaweb for instance.
Modelling for latitude and species richness alone showed that trophic diversity declined significantly towards northern latitudes and increased significantly with species richness, as expected $\left(R^{2}=0.89\right)$. Further, the latitudinal gradient of trophic diversity was fully accounted for when including environmental variables in the linear model (annual mean temperature, temperature seasonality and net primary productivity) in addition to species richness (Figure S5). More precisely, trophic diversity increased significantly with annual mean temperature and NPP, and displayed a quadratic response to temperature seasonality (i.e. mild seasonality was linked to higher trophic diversity while extreme seasonality, both high and low, was detrimental to trophic diversity; Table S1). Furthermore, results show that the environmental variables significantly affected the linear relationship between trophic diversity and species richness (Figure 3C; Figure S6, Table S1). For instance, trophic diversity was generally higher where annual mean temperatures were warmer in Europe, while holding species richness constant (Figure 3C). Conversely, in colder environments, trophic diversity was lower than explained by species richness alone. Interestingly, in colder environments, trophic diversity was also gained more quickly as species were added to the local assemblage. 


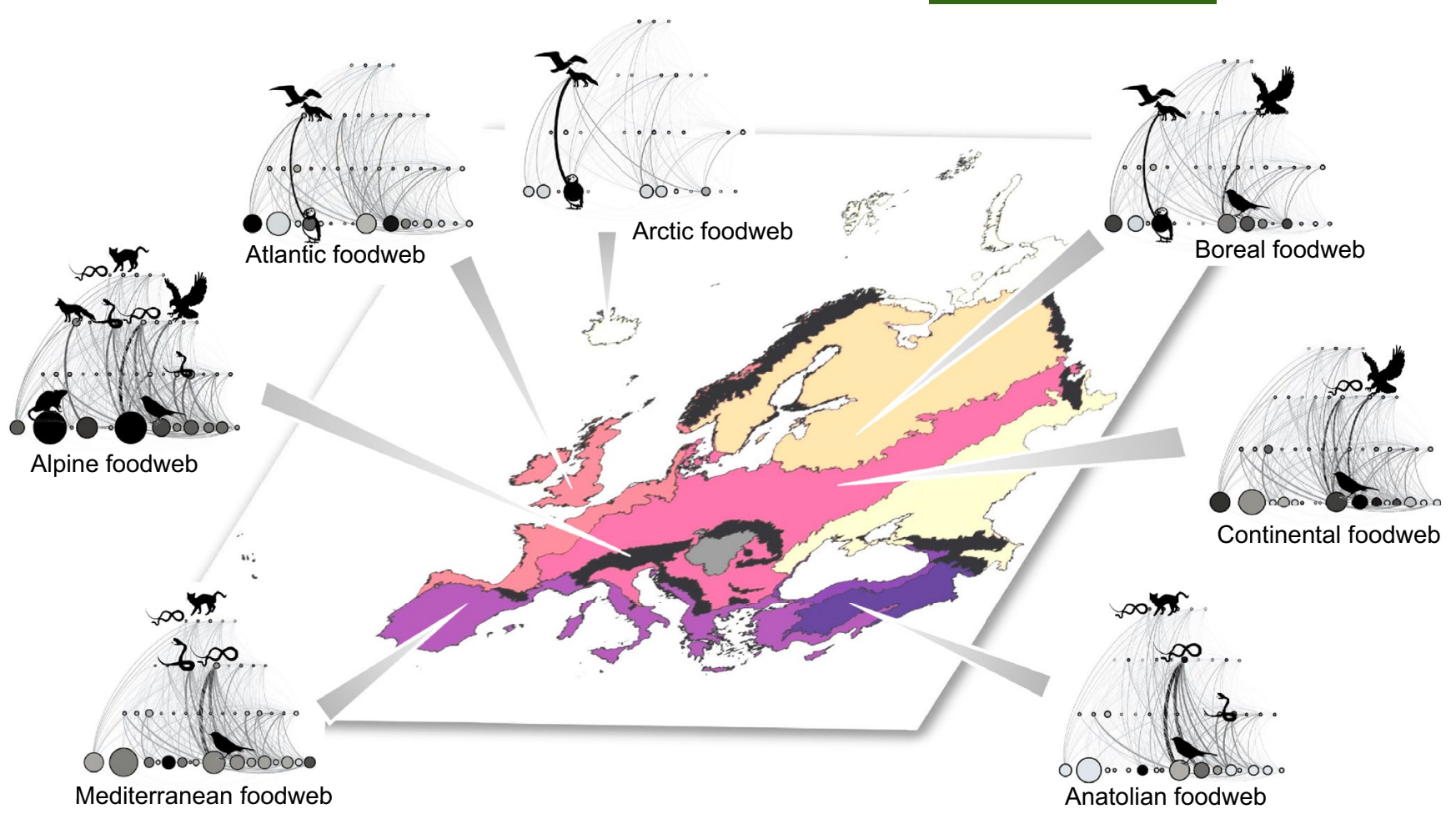

FIGURE 4 Regional metawebs of European tetrapods. The size of the nodes correspond to the number of species representing a given trophic group in the ecoregion; the width and intensity of the links represent the number of interactions that exist between two given groups in this ecoregion. Nodes are coloured according to the median specialization of the species to the ecoregion within each trophic group: the darker the node, the higher the specialization of the trophic group to the ecoregion [Colour figure can be viewed at wileyonlinelibrary.com]

\section{4 | DISCUSSION}

In this paper, we investigated the spatial structure of food webs from a functional perspective. Building on the Eltonian niche concept, we showed that species interacting in a large food web can be aggregated into a few dozen trophic groups of species with the same role in the food web using a novel network science approach, the stochastic block model. We then showed that trophic groups were coherent with the trophic level, trophic specialization, functional traits and taxonomy of species within them. Second, our analysis revealed a latitudinal gradient in trophic diversity (richness of trophic groups) that varied with the wellknown species richness gradient, but was also additionally explained by environmental conditions (e.g. warmer temperatures, mild seasonality) and net primary productivity. Taken together, these results show that the Eltonian niche provides an unmatched opportunity to unveil the structure and function of large food webs at a continental scale.

\section{1 | Recovering species' Eltonian niche from large food webs with the stochastic block model}

The stochastic block model goes further in capturing the different dimensions of a species' role in the food web than the trophic level concept, which overlooks important aspects of species' ecological role such as their taxonomy, trophic specialization and biological traits (Cirtwill et al., 2018). In addition, the trophic level is a concept that implies a hierarchy in the food web that is not always relevant (Cousins, 1987; Polis \& Strong, 1996). This is especially important for other types of networks (e.g. multiple interaction types (Pilosof, Porter, Pascual, \& Kéfi, 2017)) where there are many loops and no clear trophic levels. Conceptually, the trophic groups resulting from the stochastic block model are linked to trophic guilds since they represent a group of species that exploit the same resources, that is that have a similar role in a food web (Simberloff \& Dayan, 1991). However, the two approaches differ in methodology: while guilds are usually based on expert opinion, the stochastic block model explicitly uses the interaction network. Such a data-driven approach to identify species roles has the potential to bring to light some similarities between pairs of species that otherwise might have been ignored. In other words, the stochastic block model enables to bridge the gap between network theory and functional ecology (Gravel et al., 2016).

Furthermore, we showed that trophic groups were driven by species functional traits. The metaweb studied here included tetrapod species exclusively, therefore basal trophic groups sometimes contained secondary consumers such as piscivorous and insectivorous species, and basal groups were not always as homogenous in terms of taxonomy as trophic groups further up the trophic levels. Nonetheless, biological traits associated to species foraging and vulnerability traits explained trophic groups across all trophic levels. Unsurprisingly, diet categories and feeding behaviour strongly determined species' trophic role. Then, activity time and nesting habitat also structured the trophic groups, particularly within lower 
trophic levels. Interestingly, activity times of predators did not necessarily coincide with the activity time of their prey: indeed, nocturnal predators may preferentially feed on diurnal prey, provided that their foraging habitat coincides with their prey's nesting habitat. Overall, these results exemplify that a species' Eltonian niche (i.e. the potential occurrence of a trophic interaction), as recovered with the stochastic block model, is determined by the temporal, spatial and functional aspects of a species' ecology.

\subsection{From Eltonian niches to food web structure at macroecological scales}

In our study, we have not addressed the intraspecific variability in species interactions (Poisot, Stouffer, \& Gravel, 2014) nor the realized Eltonian niche of species, which can only be deduced from empirical food web datasets that are unavailable at macroecological scales. Besides, comparison of empirical food webs between several locations is impossible to date unless only one dimension is considered (e.g. along a linear gradient, or time: Matias \& Miele, 2017; Miele \& Matias, 2017). Instead, we have used the potential interactions that are either known or expected to occur between all tetrapod species in Europe (i.e. the metaweb, sensu Dunne, 2006), thus recovering the potential Eltonian niche of species. Indeed, if the potential niche of a species represents the set of abiotic environmental conditions in which it could thrive without accounting for its biotic interactions (Hutchinson, 1957), then the potential Eltonian niche of a species should represent the set of species that it could interact with if they coexisted.

Our results showed that trophic diversity, defined as trophic group richness or the range of Eltonian niches in an area, increased linearly with species richness across Europe, but also reveal interesting deviations from this linear relationship. We found that generally, trophic diversity was higher in southern Europe than would be explained from species richness alone, reflecting a higher niche differentiation in more favourable environments, where the climate is milder and ecosystems are more productive. Conversely, in northern Europe, in the Arctic or Boreal ecoregions for example, where climatic conditions are harsher and ecosystems less productive, trophic diversity was lower than that would be explained by species richness alone. This could be due to the absence of some trophic groups (mostly those represented by herptiles) in northern latitudes, due to their physiology (Snyder \& Weathers, 1975). In addition, in northern Europe, trophic diversity was more sensitive to species richness; as species are added to the community, they tend to fill different Eltonian niches, maximizing the trophic complementarity (Poisot et al., 2013) in these simple food webs. Our results further support earlier findings suggesting that niche breadth increases with latitude, leading to fewer niches overall in northern latitudes (Baiser et al., 2019; Cirtwill, Stouffer, \& Romanuk, 2015).

The particular case of the alpine metaweb suggests environmental heterogeneity is an additional driver of trophic diversity. The alpine metaweb contained the highest diversity in terms of species, trophic groups and types of interactions. It is well established that in the Alps, the elevational gradient combined with spatial heterogeneity naturally provide a diversity of habitats which results in a higher diversity of niches available in the Alps (Kadmon \& Allouche, 2007; Tylianakis \& Morris, 2017). Furthermore, the alpine ecoregion is a highly fragmented ecoregion, widespread across Europe, with isolated inlets in Scandinavia, the Alps, the Balkans and the Pyrenees, therefore comprising a wide variety of climatic and land cover conditions (Figure 4), which can explain high trophic diversity in the alpine metaweb.

In addition to driving regional differences in trophic diversity, different types of environments were composed of different trophic groups: some trophic groups and their interactions were specialized to certain ecoregions, supporting the well-established principle in biogeography that different environments select for different functions (Buffon, 1761), in particular different trophic roles (Tylianakis \& Morris, 2017). For example, top predator feline species and snakes predating upon smaller reptiles and rodents is a type of interaction that is particularly well-represented in the Mediterranean metaweb. On the other hand, despite regional differences in environmental conditions, some trophic groups were common to all ecoregional metawebs, which could be represented by wide-ranging, generalist species (Devictor, Julliard, \& Jiguet, 2008). More fundamentally, such similarities in the trophic composition between different ecoregions echo with Elton's conception of the niche: different communities can display convergence in ecological roles and function, even when species composition differ (Simberloff \& Dayan, 1991). Overall, our results suggest that trophic diversity is driven by the interplay between the functional traits, Eltonian niche, and geographic distribution of species and environmental conditions. Our study does not disentangle the factors upon which the environment selects species, and in fact, it would be vain to attempt to tease apart these drivers. In addition, there is a need to integrate the aspects of history together with the current biotic and abiotic conditions across space to understand diversity patterns in all of their complexity. The history of land use in particular has been shown to be a major driver of diversity patterns (Niedrist, Tasser, Lüth, Dalla Via, \& Tappeiner, 2009; Pimm \& Raven, 2000), especially in Europe where a complex history of local extinctions, species reintroductions and translocations has unfolded over the past centuries, particularly for large tetrapods such as the wolf or the bear (Chapron et al., 2014). Ultimately, our study has illustrated how the environment can filter species assembly, based on the interplay between their trophic role, biological traits and taxonomy, and further supports the relevance of using trophic diversity as a new dimension of functional diversity in an area.

\section{3 | Perspectives}

In the era of big data, there is an ever-increasing availability of information on potential interactions, together with high-resolution distribution data and life-history traits. Harnessing these data with novel developments in network science while relying on fundamental niche concepts should lead to a new approach for addressing pressing topics, such as the potential effects of environmental changes on biodiversity and ecosystem functioning, or identifying 
conservation priorities to sustain multi-trophic communities. Here, we have shown that the trophic groups inferred using the stochastic block model encompass multiple dimensions of the role of species in a community. As global change triggers communities to be disrupted and interactions to be broken, understanding the Eltonian niche of species has the potential to inform conservation planning. For example, trophic groups can help predict the impacts of species translocation as populations go locally extinct, or the invasive potential of species as their distributions shift. Overall, this study calls for the integration of multiple aspects of species' ecology to understand how they assemble across space; ecologists need to account not only for species' response to environmental gradients (i.e. their Hutchinsonian niche; Guisan \& Thuiller, 2005), but also for their biological traits, their biotic interactions and their Eltonian niche, to understand the biodiversity patterns across space and time.

\section{ACKNOWLEDGEMENTS}

The research leading to these results has received funding from the ERA-Net BiodivERsA - Belmont Forum, with the national funder Agence Nationale de la Recherche (ANR-18-EBI4-0009), part of the 2018 Joint call BiodivERsA-Belmont Forum call (project 'FutureWeb'). WT was also supported by the Agence Nationale pour la Recherche through the FORBIC (ANR-18-MPGA-0004) and EcoNet (ANR-18-CE02-0010) projects.

\section{DATA AVAILABILITY STATEMENT}

We used the data on species trophic interactions, species distributions and biological traits built by LM, GFF, WT and AM. The full dataset of trophic interactions analysed in this article, as well as the output of the stochastic block model, is archived in the Dryad data repository at https://doi.org/10.5061/dryad.bcc2fqz79.

\section{ORCID}

Louise M. J. O'Connor (iD https://orcid.org/0000-0002-6671-9144 Gentile Francesco Ficetola (iD https://orcid.

org/0000-0003-3414-5155

Wilfried Thuiller (iD https://orcid.org/0000-0002-5388-5274

\section{REFERENCES}

Allesina, S., \& Pascual, M. (2009). Food web models: A plea for groups. Ecology Letters, 12(7), 652-662. https://doi.org/10.1111/j.1461-0248. 2009.01321.x

Baiser, B., Gravel, D., Cirtwill, A. R., Dunne, J. A., Fahimipour, A. K., Gilarranz, L. J., ... Yeakel, J. D. (2019). Ecogeographical rules and the macroecology of food webs. Global Ecology and Biogeography, 28(9), 1204-1218. https://doi.org/10.1111/geb.12925

Bascompte, J. (2009). Disentangling the web of life. Science, 325(5939), 416-419. https://doi.org/10.1126/science.1170749

Bascompte, J., García, M. B., Ortega, R., Rezende, E. L., \& Pironon, S. (2019). Mutualistic interactions reshuffle the effects of climate change on plants across the tree of life. Science Advances, 5(5), eaav2539. https://doi.org/10.1126/sciadv.aav2539

Baskerville, E. B., Dobson, A. P., Bedford, T., Allesina, S., Anderson, T. M., \& Pascual, M. (2011). Spatial guilds in the Serengeti food web revealed by a Bayesian group model. PLoS Computational Biology, 7(12), https://doi.org/10.1371/journal.pcbi.1002321
Bastian, M., Heymann, S., \& Jacomy, M. (2009). Gephi: An open source software for exploring and manipulating networks. Third International AAAI Conference on Weblogs and Social Media, 361-362.

Buffon, G.-L.- L. (1761). Histoire naturelle générale et particulière.

Chapron, G., Kaczensky, P., Linnell, J. D. C., von Arx, M., Huber, D., Andrén, H., ... Boitani, L. (2014). Recovery of large carnivores in Europe's modern human-dominated landscapes. Science, 346(6216), 1517-1519. https://doi.org/10.1126/science.1257553

Cirtwill, A. R., Dalla Riva, G. V., Gaiarsa, M. P., Bimler, M. D., Cagua, E. F., Coux, C., \& Dehling, D. M. (2018). A review of species role concepts in food webs. Food Webs, 16, e00093. https://doi.org/10.1016/j. fooweb.2018.e00093

Cirtwill, A. R., Stouffer, D. B., \& Romanuk, T. N. (2015). Latitudinal gradients in biotic niche breadth vary across ecosystem types. Proceedings of the Royal Society B: Biological Sciences, 282(1819), 20151589. https:// doi.org/10.1098/rspb.2015.1589

Cousins, S. (1987). The decline of the trophic level concept. Trends in Ecology \& Evolution, 2(10), 312-316. https://doi.org/10.1016/01695347(87)90086-3

Coux, C., Rader, R., Bartomeus, I., \& Tylianakis, J. M. (2016). Linking species functional roles to their network roles. Ecology Letters, 19(7), 762-770. https://doi.org/10.1111/ele.12612

Csárdi, G. (2019). Package 'igraph': Network analysis and visualization.

Daudin, J.-J., Picard, F., \& Robin, S. (2008). A mixture model for random graphs. Statistics and Computing, 18(2), 173-183. https://doi. org/10.1007/s11222-007-9046-7

Davies, T. J., \& Buckley, L. B. (2011). Phylogenetic diversity as a window into the evolutionary and biogeographic histories of present-day richness gradients for mammals. Philosophical Transactions of the Royal Society B: Biological Sciences, 366(1576), 2414-2425. https://doi.org/10.1098/ rstb.2011.0058

Devictor, V., Julliard, R., \& Jiguet, F. (2008). Distribution of specialist and generalist species along spatial gradients of habitat disturbance and fragmentation. Oikos, 117(4), 507-514. https://doi.org/ 10.1111/j.0030-1299.2008.16215.x

Dolédec, S., Chessel, D., \& Gimaret-Carpentier, C. (2000). Niche separation in community analysis: A new method. Ecology. https://doi.org/ 10.1890/0012-9658(2000)081[2914:NSICAA]2.0.CO;2

Dray, S., Dufour, A.-B., \& Thioulouse, J. (2018). Package "ade4". https:// doi.org/10.18637/jss.v022.i04

Dunne, J. A. (2006). The network structure of food webs. Ecological networks : linking structure to dynamics in food webs.

Elton, C.S. (1927). Animal ecology. (p. 200) London: Sedgwick and Jackson.

European Environmental Agency, EEA (2019). Biogeographical regions. http://www.eea.europa.eu/data-and-maps/data/biogeographical-regionseurope-3

Ficetola, G. F., Mazel, F., \& Thuiller, W. (2017). Global determinants of zoogeographical boundaries. Nature Ecology and Evolution, 1(4), 1-7. https://doi.org/10.1038/s41559-017-0089

Ficetola, G. F., Rondinini, C., Bonardi, A., Baisero, D., \& Padoa-Schioppa, E. (2015). Habitat availability for amphibians and extinction threat: A global analysis. Diversity and Distributions, 21(3), 302-311. https:// doi.org/10.1111/ddi.12296

Gaston, K. J. (2000). Global patterns in biodiversity. Nature, 405, $220-$ 227. https://doi.org/10.1038/35012228

Gauzens, B., Thébault, E., Lacroix, G., \& Legendre, S. (2015). Trophic groups and modules: Two levels of group detection in food webs. Journal of the Royal Society Interface, 12(106), https://doi. org/10.1098/rsif.2014.1176

Gotelli, N. J., Graves, G. R., \& Rahbek, C. (2010). Macroecological signals of species interactions in the Danish avifauna. Proceedings of the National Academy of Sciences of the United States of America, 107(11), 5030-5035. https://doi.org/10.1073/pnas.0914089107

Gravel, D., Albouy, C., \& Thuiller, W. (2016). The meaning of functional trait composition of food webs for ecosystem functioning. 
Philosophical Transactions of the Royal Society B: Biological Sciences, 371(1694), https://doi.org/10.1098/rstb.2015.0268

Gravel, D., Baiser, B., Dunne, J. A., Kopelke, J.-P., Martinez, N. D., Nyman, T., ... Roslin, T. (2018). Bringing Elton and Grinnell together: A quantitative framework to represent the biogeography of ecological interaction networks. Ecography, 42(3), 401-415. https://doi.org/10.1111/ecog.04006

Guisan, A., \& Thuiller, W. (2005). Predicting species distribution: Offering more than simple habitat models. Ecology Letters, 8(9), 993-1009. https://doi.org/10.1111/j.1461-0248.2005.00792.x

Hutchinson, G.E. (1957) Concluding remarks. Cold Spring Harbor Symposia on Quantitative Biology, 22, 145-159.

Jetz, W., Thomas, G. H., Joy, J. B., Hartmann, K., \& Mooers, A. O. (2012). The global diversity of birds in space and time. Nature, 491(7424), 444-448. https://doi.org/10.1038/nature11631

Kadmon, R., \& Allouche, O. (2007). Integrating the effects of area, isolation, and habitat heterogeneity on species diversity: A unification of island biogeography and niche theory. The American Naturalist, 170(3), 443-454. https://doi.org/10.1086/519853

Karrer, B., \& Newman, M. E. J. (2011). Stochastic blockmodels and community structure in networks. Physical Review E, 83(1), 016107. https:// doi.org/10.1103/PhysRevE.83.016107

Kéfi, S., Miele, V., Wieters, E. A., Navarrete, S. A., \& Berlow, E. L. (2016). How structured is the entangled bank? The surprisingly simple organization of multiplex ecological networks leads to increased persistence and resilience. PLoS Biology, 14(8), 1-21. https://doi. org/10.1371/journal.pbio.1002527

Kortsch, S., Primicerio, R., Aschan, M., Lind, S., Dolgov, A. V., \& Planque, B. (2019). Food-web structure varies along environmental gradients in a high-latitude marine ecosystem. Ecography, 42(2), 295-308. https://doi.org/10.1111/ecog.03443

Laigle, I., Aubin, I., Digel, C., Brose, U., Boulangeat, I., \& Gravel, D. (2018). Species traits as drivers of food web structure. Oikos, 127(2), 316326. https://doi.org/10.1111/oik.04712

Luck, G. W., Lavorel, S., McIntyre, S., \& Lumb, K. (2012). Improving the application of vertebrate trait-based frameworks to the study of ecosystem services. Journal of Animal Ecology, 81(5), 1065-1076. https:// doi.org/10.1111/j.1365-2656.2012.01974.x

Maiorano, L., Amori, G., Capula, M., Falcucci, A., Masi, M., Montemaggiori, A., ... Guisan, A. (2013). Threats from climate change to terrestrial vertebrate hotspots in Europe. PLOS ONE, 8(9), 1-14. https://doi. org/10.1371/journal.pone.0074989

Mariadassou, M., Robin, S., \& Vacher, C. (2010). Uncovering latent structure in valued graphs: A variational approach. The Annals of Applied Statistics, 4(2), 715-742. https://doi.org/10.1214/10-AOAS361

Matias, C., \& Miele, V. (2017). Statistical clustering of temporal networks through a dynamic stochastic block model. Journal of the Royal Statistical Society: Series B (Statistical Methodology), 79(4), 1119-1141. https://doi.org/10.1111/rssb.12200

Mazel, F., Wüest, R. O., Lessard, J.-P., Renaud, J., Ficetola, G. F., Lavergne, S., \& Thuiller, W. (2017). Global patterns of $\beta$-diversity along the phylogenetic time-scale: The role of climate and plate tectonics. Global Ecology and Biogeography, 26(10), 1211-1221. https://doi.org/10.1111/geb.12632

Miele, V. (2006). MixeR package.

Miele, V., \& Matias, C. (2017). Revealing the hidden structure of dynamic ecological networks. Royal Society Open Science, 4(6), 170251. https:// doi.org/10.1098/rsos.170251

Newman, M. E. J., \& Leicht, E. A. (2007). Mixture models and explanatory analysis in networks. Proceedings of the National Academy of Sciences of the United States of America, 99(12), 7821-7826. https:// doi.org/10.1073/pnas.122653799

Niedrist, G., Tasser, E., Lüth, C., Dalla Via, J., \& Tappeiner, U. (2009). Plant diversity declines with recent land use changes in European Alps. Plant Ecology, 202(2), 195-210. https://doi.org/10.1007/s11258-008-9487-x

Pellissier, L., Albouy, C., Bascompte, J., Farwig, N., Graham, C., Loreau, M., ... Gravel, D. (2017). Comparing species interaction networks along environmental gradients. Biological Reviews, 93(2), 785-800. https://doi.org/10.1111/brv.12366

Pilosof, S., Porter, M. A., Pascual, M., \& Kéfi, S. (2017). The multilayer nature of ecological networks. Nature Ecology \& Evolution, 1(4), 0101. https://doi.org/10.1038/s41559-017-0101

Pimm, S. L., \& Raven, P. (2000). Extinction by numbers. Nature, 403(6772), 843-845. https://doi.org/10.1038/35002708

Poisot, T., Mouquet, N., \& Gravel, D. (2013). Trophic complementarity drives the biodiversity-ecosystem functioning relationship in food webs. Ecology Letters, 16(7), 853-861. https://doi.org/10.1111/ele.12118

Poisot, T., Stouffer, D. B., \& Gravel, D. (2014). Beyond species : why ecological interaction networks vary through space and time. (August), 1-9. https://doi.org/10.1111/oik.01719

Polis, G. A., \& Strong, D. R. (1996). Food web complexity and community dynamics. The American Naturalist, 147(5), 813-846. https://doi. org/10.1086/285880

R Core Team. (2017). R: A language and environment for statistical computing. Vienna, Austria: R Foundation for Statistical Computing. Retrieved from https://www.R-project.org/

Rossberg, A. G., Brännström, A., \& Dieckmann, U. (2010). Food-web structure in low-and high-dimensional trophic niche spaces. Journal of the Royal Society, 7, 1735-1743. https://doi.org/10.1098/rsif.2010.0111

Safi, K., Cianciaruso, M. V., Loyola, R. D., Brito, D., Armour-Marshall, K., \& Diniz-Filho, J. A. F. (2011). Understanding global patterns of mammalian functional and phylogenetic diversity. Philosophical Transactions of the Royal Society B: Biological Sciences, 366(1577), 2536-2544. https://doi.org/10.1098/rstb.2011.0024

Simberloff, D., \& Dayan, T. (1991). The guild concept and the structure of ecological communities. Annual Review of Ecology and Systematics, 22(1), 115-143. https://doi.org/10.1146/annurev.es.22.110191.000555

Snyder, G. K., \& Weathers, W. W. (1975). Temperature adaptations in amphibians. The American Naturalist, 109(965), 93-101. https://doi. org/10.1086/282976

Soetaert, K., Kipyegon Kones, J., \& van Oevelen, D. (2015). Package 'NetIndices': Estimating network indices, including trophic structure of foodwebs in $R$.

Sundstrom, S. M., Allen, C. R., \& Barichievy, C. (2012). Species, functional groups, and thresholds in ecological resilience. Conservation Biology, 26(2), 305-314. https://doi.org/10.1111/j.1523-1739.2011.01822.x

Thompson, R. M., Brose, U., Dunne, J. A., Hall, R. O., Hladyz, S., Kitching, R. L., ... Tylianakis, J. M. (2012). Food webs: Reconciling the structure and function of biodiversity. Trends in Ecology and Evolution, 27(12), 689-697. https://doi.org/10.1016/j.tree.2012.08.005

Thuiller, W., Maiorano, L., Mazel, F., Guilhaumon, F., Ficetola, G. F., Lavergne, S., ... Mouillot, D. (2015). Conserving the functional and phylogenetic trees of life of European tetrapods. Philosophical Transactions of the Royal Society B: Biological Sciences, 370(1662), 1-12. https://doi. org/10.1098/rstb.2014.0005

Tylianakis, J. M., Didham, R. K., Bascompte, J., \& Wardle, D. A. (2008). Global change and species interactions in terrestrial ecosystems. Ecology Letters, 11(12), 1351-1363. https://doi.org/10.1111/j.1461-0248.2008.01250.x

Tylianakis, J. M., \& Morris, R. J. (2017). Ecological networks across environmental gradients. Annual Review of Ecology, Evolution, and Systematics, 48(1), 25-48. https://doi.org/10.1146/annurev-ecolsys-110316-022821

Valiente-Banuet, A., Aizen, M. A., Alcántara, J. M., Arroyo, J., Cocucci, A., Galetti, M., ... Zamora, R. (2015). Beyond species loss: The extinction of ecological interactions in a changing world. Functional Ecology, 29(3), 299-307. https://doi.org/10.1111/1365-2435.12356

Van der Putten, W. H., Macel, M., \& Visser, M. E. (2010). Predicting species distribution and abundance responses to climate change: Why it is essential to include biotic interactions across trophic levels. Philosophical Transactions of the Royal Society B: Biological Sciences, 365(1549), 2025-2034. https://doi.org/10.1098/rstb.2010.0037

von Humboldt, A., \& Bonpland, A. (1805). Essai sur la géographie des plantes. 
Wisz, M. S., Pottier, J., Kissling, W. D., Pellissier, L., Lenoir, J., Damgaard, C. F., ... Svenning, J.-C. (2013). The role of biotic interactions in shaping distributions and realised assemblages of species: Implications for species distribution modelling. Biological Reviews, 88(1), 15-30. https://doi.org/10.1111/j.1469-185X.2012.00235.x

\section{BIOSKETCH}

Louise O'Connor recently started a $\mathrm{PhD}$ aiming to understand the influence of interaction networks on predictions of biodiversity patterns in the context of global change, in order to better inform conservation planning.

Author contributions: WT, LJP and LOC conceptualized and wrote the paper. LM, GFF, WT and AM built the trophic and trait data. LOC carried out the analyses with the help of JB, LJP, WT and $\mathrm{MO}$. CMA and $\mathrm{MO}$ gave additional perspectives to the paper. All authors contributed significantly to the manuscript.

\section{SUPPORTING INFORMATION}

Additional supporting information may be found online in the Supporting Information section.

How to cite this article: O'Connor L, Pollock LJ, Braga J, et al. Unveiling the food webs of tetrapods across Europe through the prism of the Eltonian niche. J Biogeogr. 2020;47:181-192. https://doi.org/10.1111/jbi.13773

\section{APPENDIX 1 \\ LIST OF REFERENCES USED TO BUILD THE METAWEB OF TROPHIC INTERACTIONS BETWEEN EUROPEAN TETRAPOD SPECIES}

The trophic links for mammals were compiled from the Handbook of the Mammals of the World composed of nine volumes (Wilson and Mittermeier 2009-2019). Furthermore, we considered multiple books on the mammalian fauna of the single countries and all volumes of Mammalian Species (published by the American Society of Mammalogists) available for species included in the database. The trophic links for breeding birds were compiled from the Handbook of the Birds of Europe, the Middle East and North Africa ( 9 volumes; Cramp et al. 1977-1994), the Handbook of the Birds of the World (16 volumes; del Hoyo et al 1992-2013), and the Handbook of the Birds of the World Alive website (del Hoyo et al. 2014). The trophic links for amphibians and reptiles were compiled from the Handbuch der Reptilien und Amphibien Europas (Arntzen et al. 1999; Bohme 1984; Fritz 2001; Grossenbacher and Thiesmeier 2003; Thiesmeier et al. 2004) plus multiple books and papers on the herpetofauna of the single countries. Trophic links for each species were compiled by the authors using a standardized data input protocol in MS Excel. For each species, we included in the database all trophic links reported in the publications using the highest possible taxonomic detail. Most of the time the information was available at the level of family or higher; for instance, the food habits of Falco tinnunculus (the common kestrel) are described as: "in Europe up to $90 \%$ voles, with some mice and shrews; open area passerines normally less important [...]; also lizards and insects [...]", therefore we included as potential prey species all mammals of the families Arvicolinae, Muridae, and Soricidae, all birds of the family Alaudidae, and all reptiles of the family Lacertidae.

\section{REFERENCES}

Arakelyan, M. S., Dalielyan, F. D., Corti, C., Sindaco, R., Leviton, A. E. (2011). Herpetofauna of Armenia and Nagorno-Karabakh. Society for the Study of Amphibians and Reptiles. Ithaca, NY: USA.

Arnold, E. N. (1987). Resource partition among lacertid lizards in southern Europe. Journal of Zoology (B), 1, 739-782.

Arntzen, J. W., Bohme, W., \& Grossenbacher, K. (Eds.). (1999). Handbuch der Reptilien und Amphibien Europas. Bd. 4/I. Schwanzlurche (Urodela) I(Hynobiidae, Proteidae, Plethodontidae, Salamandridae I: Pleurodeles, Salamandrina, Euproctus, Chioglossa, Mertensiella). Wiesbaden: AULA-Verlag.

Arntzen, J. W. (2003). Handbuch der Reptilien und Amphibien Europas Schwanzlurche IIA.

Atatür, M.K., Göçmen, B., 2001. Amphibians and Reptiles of Northern Cyprus. Ege Üniversitesi, Fen Fakültesi Kitaplar Serisi, No. 170, Ege Üniversitesi Basimevi, Bornova-Izmir.

Baran, I., \& Atatür, M. K. (1998). Turkish herpetofauna: Amphibians and reptiles. Turkey: Ministry of Environment.

Böhme, W. (1981). Handbuch der reptilien und amphibien Europas.

Böhme, W. (Ed.). (1984). Handbuch der Reptilien und Amphibien Europas, Band 2/I: Echsen (Sauria) II Lacertidae II: Lacerta. Wiebelsheim: AULA-Verlag.

Blaustein, L., Friedman, J., \& Fahima, T. (1996). Larval Salamandra drive temporary pool community dynamics: Evidence from an artificial pool experiment. Oikos, 76, 392-402.

Carascal, L. M., Salvador, A. (Eds.). (2005). Enciclopedia Virtual de los Vertebrados Españoles. Madrid: Museo Nacional de Ciencias Naturales.

Carretero, M. A., Roca, V., Martin, J. E., Llorente, G. A., Montori, A., Santos, X., \& Mateos, J. (2006). Diet and helminth parasites in the Gran Canaria giant lizard, Gallotia stehlini. Revista Española de Herpetología, 20, 105-117.

Cicek, K., Tok, C. V., Mermer, A., Tosunoglu, M., Ayaz, D. (2007). Food habits of the Lycian Salamander, Lyciasalamandra fazilae (Basoglu and Atatur, 1974): Preliminary data on Dalyan population. NorthWestern Journal of Zoology, 3, 1-8.

Corti, C., \& Lo Cascio, P. (2002). The lizards of Italy and Adjacent Areas. Frankfurt: Chimaira.

Corti, C., Capula, M., Luiselli, L., Razzetti, E., Sindaco, R. (2011). Fauna d'Italia, vol. XLV, Reptilia. Bologna: Calderini.

Cramp, S., \& Simmons, K. E. L. (1977-1994). Handbook of the birds of Europe, Middle East and North Africa, 1, 722.

Danilov, I. G., \& Moravec, J. (2005). Handbuch der Reptilien und Amphibien Europas.

Del Hoyo, J., Elliott, A., \& Sargatal, J. (1992-2013). Handbook of the birds of the world. Barcelona: Lynx edicions.

Del Hoyo, J., Elliott, A., Sargatal, J., Christie, D. A., \& de Juana, E. (2014). Handbook of the birds of the world alive. Barcelona: Lynx Edicions,

Dimaki, M. H., Valakos, E. D., Chondropoulos, B., \& Bonetti, A. (2000). Preliminary results on the feeding ecology of the African Chamaleon Chamaleo africanus Laurenti, 1768 from the southwestern Peloponnese, Greece. In E. Valakos, P. Lymberakis, P. Pafilis, \& M. Mylonas (Eds.), Herpetologia Candiana. Irakleio Crete: Museum of Crete, Societas Europaea Herpetologica.

Dusen, S. (2012). First data on the helminth fauna of a locally distributed mountain frog, "Tavas frog" Rana tavasensis Baran \& Atatur, 1986 
(Anura: Ranidae), from the inner-west Anatolian region of Turkey. Turkish Journal of Zoology, 36, 496-502.

Fritz, U. (Ed.). (2001). Handbuch der Reptilien und Amphibien Europas, Band 3/IIIA: Schildkröten (Testudines) I (Bataguridae, Testudinidae, Emydidae). Wiebelsheim: AULA-Verlag.

Gil, V. F. (2011). Crescimento individual da osga-das-Selvagens (Tarentola bischoffi): influências das variações sazonais na disponibilidade alimentar. MsC Thesis, Univ. Lisboa, Lisboa, Portugal.

Grbac, I., Leiner, S., Perović, F. (2001). Thermoregulation and diet composition of insular populations of Podarcis melisellensis and Lacerta oxycephala. Biota, 2, 38.

Grossenbacher, K., Thiesmeier, B. eds., 2003. Handbuch der Reptilien und Amphibien Europas. Bd. 4/IIA: Schwanzlurche (Urodela) IIA. Wiesbaden: AULA-Verlag.

Hokayem, M. L., Bloquet, S. H., Sadek, R., Saade, J. H. (2006). Régime alimentaire d'une population d'Acanthodactylus schreiberi syriacus Böttger, 1879 (Reptilia Lacertidae) de la côte sud du Liban. Bulletin de la Société Herpetologique de France, 119, 17-25.

Keller, M. (2005). Ethology and Ecology of the Nile Soft-shelled Turtle Trionyx triunguis in Dalyan, Turkey. Biologisches Institut, Abteilung Zoologie. Universität Stuttgart, Stuttgart.

Khan, M. S. (2006). Amphibians and reptiles of Pakistan. Malabar, Florida: Krieger Publishing Company.

Kreiner, G. (2007). The snakes of Europe. Chimaira, Frankfurt am Main.

Lanza, B., Andreone, F., Bologna, M. A., Corti, C., Razzetti, E. (Eds.). (2007). Fauna d'Italia, vol. XLII, Amphibia. Calderini, Bologna.

Mahlow, K., Tillack, F., Schmidtler, J. F., Mueller, J. (2013). An annotated checklist, description and key to the dwarf snakes of the genus Eirenis JAN, 1863 (Reptilia: Squamata: Colubridae), with special emphasis on the dentition. Vertebrate Zoology, 63, 41-85.

Mishagina, J. V. (2007). On Food Habits of Sand Racerunner, Eremias scripta (Strauch, 1867) (Squamata, Lacertidae) from Barchan Sands of Eastern Kara Kum (Repetek Reserve). Russian Journal of Herpetology, 14, 50-56.

Mishagina, J. V. (2008). Ecological groups of preys in Eastern Kara Kum psammobiont lizards, Eremias (Lacertidae) and Phrynocephalus (Agamidae), In N. B. Ananjeva, I. G. Danilov, E. A. Dunayev, V. G. Ishchenko, G. A. Lada, S. N. Litvinchuk, V. F. Orlova, E. M. Smirina, B. S. Tuniyev, \& R. G. Khalikov (Eds.), The Problems of Herpetology (Proceedings of the 3rd Meeting of the Nikolsky Herpetological Society). Saint-Petersburg: Russian Academy of Sciences.

Mobaraki, A., \& Mola, A. (2011). Mesopotamian soft shell turtle (Rafetus Euphraticus), the strangest turtle of the Middle East. Wildlife Middle East 5, 6.

Nöllert, A., \& Nöllert, C. (1992). Die Amphibien Europas. Kosmos, Stuttgart.

Orlov, N., Ananjeva, N., Khalikov, R. (2002). Natural history of pitvipers in Eastern and Southeastern Asia, In G. Schuett, M.
Hoggren, M. Douglas, \& H. Greene (Eds.), Biology of the Vipers (pp. 345-360).

Petzold, H. G. (1977). Eremias velox caucasica, Lantz, 1928; Schneller Kaukasus-Wüstenrenner. Aquarien und Terrarien 24, 358a.

Salvador, A. ed., 1998. Fauna Iberica Vol. 10. Reptiles. Museo Nacional de Ciencias Naturales \& Consejo Superior de Investicaciones Cientificas, Madrid.

Schleich, H. H., Kästle, W., Kabish, K. (1996). Amphibians and reptiles of North Africa. Koeltz, Koenigstein, Germany.

Speybroeck, J., Beukema, W., Bok, B., Van Der Vot, J., \& Velikov, I. (2016). Field Guide to the Amphibians \& Reptiles of Britain and Europe. London: Bloomsbury Publishing.

Rezazadeh, E., Kiabi, B. H., \& Ahmadzadeh, F. (2010). Contribution to the knowledge of Iranolacerta brandtii De Filippi 1863 (Sauria: Lacertidae) from the northwest of Iran. Russian Journal of Herpetology, 17, 223-230.

Thiesmeier, B., Grossenbacher, K., Franzen, M., Teunis, S. F. M., \& SchmidtLoske, K. (Eds.) (2004). Handbuch der Reptilien und Amphibien Europas. Bd. 4/IIB: Schwanzlurche (Urodela) IIB: Salamandridae III: Triturus 2, Salamandra. Wiesbaden: AULA-Verlag.

Thiesmeier, B., \& Grossenbacher, K. (2004). Handbuch der Reptilien und Amphibien Europas. Band, 4, 761-1149.

Valakos, E. D., Pafilis, P., Sotiropoulos, K., Lymberakis, P., Maragou, P., \& Foufopoulos, J. (2008). The Amphibians and Reptiles of Greece. Chimaira, Frankfurt am Main.

Wilson, D. E., \& Mittermeier, R. A. (2009-2019). Handbook of the Mammals of the World. Vols. 1 - 9. Barcelona: Lynx Edicions.

Wilson, D. E., \& Mittermeier, R. A. (2011). Handbook of the Mammals of the World. Vol. 2. Hoofed Mammals. Barcelona: Lynx Edicions.

Wilson, D. E., \& Mittermeier, R. A. (2014). Handbook of the mammals of the world: volume 4, sea mammals. Barcelona, Spain: Lynx Edicions.

Wilson, D. E., Mittermeier, R. A., Hardback, E., \& is preceded by Volume, I. (2015). Handbook of mammals of the world: 5. Monotremes and marsupials.

Wilson, D. E., Mittermeier, R. A., Ruff, S., Martínez-Vilalta, A., \& Cavallini, P. (Eds.). (2016). Handbook of the Mammals of the World: Lagomorphs and Rodents I.

Wilson, D. E., Lacher, T. E., \& Mittermeier, R. A. (Eds.). (2017). Handbook of the Mammals of the World: Rodents II. Lynx Edicions.

Zachos, Frank E. "Handbook of the Mammals of the World. Vol. 8. Insectivores, Sloths and Colugos, DE Wilson and RA Mittermeier (chief editors). Lynx Edicions, Bar

Zinner, D., Fickenscher, G. H., Roos, C., Mittermeier, R. A., Rylands, A. B., \& Wilson, D. E. (2013). Handbook of the Mammals of the World. Vol.3. Primates. 